\title{
Work-life Balance Decision-making of Norwegian Students: Implications for Human Resources Management
}

\author{
Remigiusz Gawlik, Gorm Jacobsen
}

\begin{tabular}{|c|c|}
\hline & A B STRACT \\
\hline $\begin{array}{l}\text { Objective: } \mathrm{T} \\
\text { balance dete } \\
\text { cations for } \mathrm{h}\end{array}$ & $\begin{array}{l}\text { aper aims at identifying and assessing the significance of work-life } \\
\text { nants between the Youth of highly developed societies and its impli- } \\
n \text { resources management on the example of Norway. }\end{array}$ \\
\hline $\begin{array}{l}\text { Research De } \\
\text { recruited am } \\
\text { sis, two-sta } \\
\text { based on a } \\
\text { choice quali } \\
\text { ed group dis }\end{array}$ & $\begin{array}{l}\text { \& Methods: The research target group consists of } 236 \text { respondents } \\
\text { Norwegian tertiary education students. It employed literature analy- } \\
\text { xploratory research: direct individual in-depth interviews, survey } \\
\text { administered, web-based questionnaire with single-answer, limited } \\
\text { \& quantitative, as well as explanatory research (informal moderat- } \\
\text { ons). }\end{array}$ \\
\hline $\begin{array}{l}\text { Findings: Th } \\
\text { tiveness of I } \\
\text { developmen } \\
\text { observed in }\end{array}$ & $\begin{array}{l}\text { earch on perceptions of determinants of quality of life and attrac- } \\
\text { ategies shows that in a country with relatively high socio-economic } \\
\text { l, such as Norway, differences in rankings do exist. They can be } \\
\text { ance to both material and non-material QoL determinants. }\end{array}$ \\
\hline $\begin{array}{l}\text { Implication } \\
\text { individually } \\
\text { will result i } \\
\text { adaptation }\end{array}$ & $\begin{array}{l}\text { commendations: The study revealed a need for deeper research on } \\
\text { early decision-making of future employees and entrepreneurs. This } \\
\text { r modelling of socio-economic phenomena, including more accurate } \\
\text { ids on the labour market and creation of new business models. }\end{array}$ \\
\hline $\begin{array}{l}\text { Contributic } \\
\text { perception } \\
\text { socio-econc }\end{array}$ & $\begin{array}{l}\text { lalue Added: Research value added comes from the comparison of } \\
\text { uality of life determinants between countries at various stages of } \\
\text { levelopment and its implications for human resource management. }\end{array}$ \\
\hline $\begin{array}{l}\text { Article type: } \\
\text { Keywords: }\end{array}$ & $\begin{array}{l}\text { research paper } \\
\text { determinants of quality of life; work-life balance; qualitative- } \\
\text { quantitative research; human resources; decision-making }\end{array}$ \\
\hline JEL codes: & I31, J22, J24, 015 \\
\hline Received: & Accepted: 6 August 2016 \\
\hline
\end{tabular}

Suggested citation:

Gawlik, R., \& Jacobsen, G. (2016). Work-life Balance Decision-making of Norwegian Students: Implications for Human Resources Management. Entrepreneurial Business and Economics Review, 4(4), 153-170, DOI: http://dx.doi.org/10.15678/EBER.2016.040410 


\section{INTRODUCTION}

The presented paper is a continuation of research on multicriteria decision-making processes of young people at the verge of entering what is commonly called "adult life". Main stratification criterion was the stage of actual socio-economic development of respondents' country of residence. Former stages have been described in (Gawlik, 2013, 2014; 2015; Gawlik, Titarenko \& Titov, 2015). The importance of the topic lies in the fact that an early elaboration of individual hierarchy of determinants of human life quality, including work-life balance, can enhance the ability of Youth to make conscious choices about their professional careers and personal development. Most possibly it will result in improving their future work-life balance, which in turn bears implications for human resources management (HRM).

The objective of the paper is to present the perceptions of Norwegian respondents in the field of research mentioned above. It covers a well-developed country (both economically and socially), with high legal and societal standards, relatively low level of discrepancies in the division of welfare and corruption, strongly developed social services, relatively high level of safety, etc.

The research methodology employed included (i) literature analysis; (ii) two-stage exploratory research: direct individual in-depth interviews with groups of students (stage one); survey: self-administered, web-based questionnaire with single-answer, limited choice questions of qualitative \& quantitative nature; two questions asked for ratings of significance of particular determinants of quality of life (QoL determinants), with hierarchy derived from the Likert-type scale (stage two); (iii) explanatory research (informal moderated group discussions). The research target group has been composed of 236 respondents recruited between Norwegian tertiary education students.

The following sections will present the results of literature analysis, research methodology, target group and sample, research findings and their discussion, as well as conclusions, suggestions for future deepening of the research and its possible limitations.

\section{LITERATURE REVIEW AND THEORY DEVELOPMENT}

\section{Quality of Life \& Work-life Balance}

Quality of life (QoL) studies derive from medical science, where they have been present for past 2 centuries. In Western psychological research the idea of balancing various aspects of one's activity has first appeared in the works of Perls $(1942 ; 1969)$ and Perls, Hefferline \& Goodman (1951). Economic researchers acknowledged the problem quite early, starting from Smith pointing at the happiness of human beings coming from such qualitative determinants as health, wealth and conscience (Smith, 1759, p. 45). Recently, Anand, Krishnakumar \& Tran (2011) searched for a generalisation of the understanding of the term welfare economics in Sen's (1979; 1985; 1992; 1993; 1999) Capability Approach. They underline that additionally to the importance of happiness "so are the opportunities to do things that people have reason to value and these capabilities should be integral to the assessment of a person's welfare" (Anand, Krishnakumar \& Tran, 2011, p. 205). This broadened definition served as a base for one of currently most popular measures of economic development, which is the United Nations' Human Development 
Index (HDI). Numerous research aims to link individual human perceptions of QoL with various fields of economics, just to name Maslow (1954), Abel-Smith and Townsend (1965), Atkinson (1983; 2003), Sen (1985; 1992), Schuessler and Fisher (1985), Layard (2005), Stiglitz, Sen and Fitoussi (2009), Alkire and Foster (2011), Şerban-Oprescu (2012), Chang, Travaglione and O'Neill (2015), Tang and Hornung (2015), Ulman and Šoltés (2015), Neumark and Muz (2016), Simkins and Peterson (2016), Uysal, Sirgy, Woo and Kim (2016) and others. Recently a growing number of publications with focus on combining private and professional life, i.e. work-life balance, can be observed (e.g. Adame, Caplliure \& Miquel, 2016; Ren \& Caudle, 2016; Russo, Shteigman \& Carmeli, 2016; Zheng, Kashi, Fan, Molineux \& Shan, 2016).

\section{Socio-economic Development}

Despite the presence of the term in economic literature since at least three decades, it is hard to find one consistent definition of socio-economic development. Many attempts focus rather on defining the term through its various aspects, without proposing a consistent synthetic definition. Stec, Filip, Grzebyk and Pierscieniak (2014, p. 505) state that socio-economic development is "a series of changes in a country's socio-economic life that leads to improvements in human life as well as a better organization of structures and processes taking place in a given country". Although many measures of singular aspects of socio-economic development level can be found in literature (Khan, 1990), the researchers still argue about the composition of an aggregate index. Again, an interesting attempt in this field has been presented by Stec et al. (2014).

As most reflections on socio-economic development mention its sustainability as an important factor, it is justified to explain this term as well. Urbaniec (2015, p. 120) quotes the definition of sustainable development by the World Commission on Environment and Development, which says that "sustainable development is defined as one that seeks to meet the needs of the present generation without compromising the ability to meet the needs of future generations". Ginevičius, Gedvilaite and Bruzgè (2015, p. 142) state that: "the sustainability of (...) any (...) social-economic system is usually analysed in terms of three aspects: economic, social and environmental. (...) Each of these aspects can only be defined by multiple indicators since each aspect constitutes a complex and integrated process which in practice manifests multiple characteristics, features, etc."

Socio-economic development can be operationalised as a set of features that is assured by a country. Signals of its high level in Norway came from the following: (i) general efficiency of the socio-economic system (i.e. private and public sector give efficient solutions to citizens - private sector in market goods, public sector in social services); (ii) high societal standards (awareness of value of democracy and freedom, high transparency in public and private sectors, confidence-based children education, critical attitude towards information and individual happiness perceived as important values); (iii) high material standard of living (high level of income and business capitalization, but also relatively flat distribution of income; transparency); (iv) feeling of security provided by the welfare state (easily accessible education and healthcare, reliable retirement pension system, developed infrastructure, support in case of unemployment or business failure); (v) equal opportunities for all citizens in various fields of professional activities all over the country (balanced regional development outside the Capital, similar income level regardless of branch of industry, entrepreneurship support with focus on business, 
not on field of activity - industry neutral policy); (vi) accessibility of public service to all citizen (regardless the age, race, religion, gender, disabilities, etc.); (vii) tolerance for limited occasional waste of resources, including human ones (not laziness, but acceptance of human fallibility); (viii) different expectations from public and private sector (e.g. private sector should rise the efficiency in use of resources, public should focus on quality of service); (ix) different measures of efficiency for private and public sector (e.g. in public sector, the role of material element is to keep sustainability of public service, but quality of service lies elsewhere - in private sector growth of material resource is the main aim; customer satisfaction not always credible in public sector; the ratio of public/private providers differs between sectors - e.g. education could be partially privatised, health care much less); ( $x$ ) coexistence of traditional and social forms of entrepreneurship; (xi) acceptance of changeability of social preferences in time.

Last two determinants need clarification. While discussing entrepreneurship Żur $(2015$, p. 77$)$ explains that: "the major difference (between traditional and social entrepreneurship) lies at the entrepreneur's priorities. Social entrepreneurs are driven by the primacy of social goals, but they do not deny profit generation. Their economic activity and revenue streams serve their social mission. They apply market instruments within the social arena. Traditional entrepreneurs are driven by the primacy of profit generation, although they do often introduce positive social changes in their environment (e.g. by providing employment opportunities or various CSR initiatives), which are sideeffects of their economic activity".

Jungeilges and Theisen (2008, p. 1110) notice that: "social preferences (of individuals, e.g. work-life balance decision-making) are not necessarily stable. Rather, they may evolve over time as a complicated function of socio-economic conditions experienced in the past and future socio-economic prospects".

\section{Human Resources Management}

Pocztowski (2008, p. 33) defines Human Resources Management (HRM) by explaining the notion of human resource: "people are not a resource, but dispose of a resource - an entity of embodied features and characteristics, which allow them to perform various roles in an organization". Huselid, Jackson and Schuler (1997, pp. 172-173) divide HRM into technical and strategic, where: "technical HRM activities (...) include recruiting, selection, performance measurement, training, and the administration of compensation and benefits, (whereas) strategic HRM activities (...) involve designing and implementing a set of internally consistent policies and practices that ensure a firm's human capital contributes to the achievement of its business objectives (...) and include team-based job designs, flexible workforces, quality improvement practices, employee empowerment, studies designed to diagnose a firm's strategic needs, and planned development of the talent".

Jackson, Schuler and Jiang (2014, pp. 3-5) see the main qualities of strategic HRM in focusing on HRM Systems, which are collectively managed and developed by managers, HR professionals and company employees; this in turn provides a contextualization of whole HRM; additionally, assessment of HRM effectiveness is provided from various angles by internal, multiple stakeholders. In technical HRM effectiveness evaluation comes from external stakeholders, such as the government and professional organiza- 
tions (Huselid, Jackson \& Schuler, 1997, p. 172; Baron, Jennings \& Dobbin, 1988; Tolbert \& Zucker, 1983). This study refers rather to the strategic HRM concept.

Between most important elements of the human resource Pocztowski (2008, p. 33) enumerates: "the knowledge, capacities, abilities, health, attitudes, values and motivation (and underlines further that) the owners of human resource are particular employees and this is for them to decide about the level of involvement of this resource at work".

This limits the power of an organization over human resources, which in turn increases the role of individual motivation of particular employees in overall success of endeavours of their business organization. Alfes, Shantz, Truss and Soane (2013, pp. 330331) enumerate four areas where HRM interferes with favourable individual and organizational level outcomes, by saying: "first, it has been suggested that firm-level outcome variables may in fact be too distal to assess the impact of micro-level HRM interventions (...); second, in order to examine the influence of HRM practices on employee behaviour (...) it is important to focus on how employees perceive those practices, rather than relying on accounts of the intentions behind HRM practices at a strategic level (...); third, further research is needed to unearth the mechanisms through which HRM practices impact upon individual behaviours (...); fourth, (...) research has yet to take into account how moderating variables might affect the relationship between engagement and individual behaviours".

At the same time Kehoe and Wright (2013, p. 367) mention that: "studies of the HR-performance relationship have provided limited insight into the effects of highperformance HR systems on the more proximal employee outcomes that they are likely to affect most directly". Finally, Gries and Naudé (2011) propose a model linking entrepreneurship and human development, in which they derive the occupational choice of owners of human resource from their individual assessment of entrepreneurial functioning, including the ratio between entrepreneurial and non-entrepreneurial activities.

Recently, a growth of interest in assuring the sustainability of human resources by linking HRM with social well-being (including QoL and work-life balance) can be observed (e.g. Boreham, Povey \& Tomaszewski, 2016; Kirk, 2016; Lub, Bal, Blomme \& Schalk, 2016; Parakandi \& Behery, 2016; Presbitero, Roxas \& Chadee, 2016). As individual perceptions and human capabilities are being increasingly perceived as crucial for effective HRM, HR managers should focus on motivations, perceptions and preferences of their future employees. It is though crucial to analyse their decision-making patterns, including work-life balance and preferred life strategies.

\section{MATERIAL AND METHODS}

The presented research was carried out Norway in order to provide data for the model from a socio-economically developed society (former research focused on countries at different stages of socio-economic development - Russia and South Africa). The target group of the research was young people permanently living in Norway, that are in the final period of their education and are planning to start their professional life in the nearest future or recently did so. The research sample has been composed of 236 respondents recruited among Norwegian tertiary education students. Respondents were affiliated as regular students of the University of Agder (from Kristiansand and Grimstad 
Campuses) and of Lillehammer College. Their background education varied, although economics and social sciences were predominant. The questionnaire has been addressed to all students of mentioned institutions, but the participation in the research was voluntary. A clear request about a serious and in-depth approach to the questionnaire has been formulated. No participation incentives of any kind have been proposed.

The main research hypothesis states that an early elaboration of individual hierarchy of QoL determinants, including work-life balance, can enhance the ability of Youth to make conscious choices about their future professional careers and personal development.

The research methodology consisted of three consecutive steps. Firstly a search for available scientific literature on the matter has been performed, with a special focus on socio-economic development, QoL determinants, work-life balance and specifics of HRM decision-making. In second step a two-stage exploratory research has been performed. Direct individual in-depth interviews with groups of students aimed at providing the authors with general ideas on their perceptions of social, economic and geopolitical environment they live in. In order to obtain a more structured knowledge, a selfadministered, web-based questionnaire followed. The survey was composed mostly of single-answer, limited choice questions. In order to provide a possibly large insight, as well as data for future application of Analytic Hierarchy Process modelling some of them were of qualitative, other of quantitative nature. Two of the questions asked for ratings of significance of particular QoL determinants. In one case the answer gradation was based on a Likert-type scale, in the other it requested to group answers in a hierarchy of descending order. Finally, explanatory research followed. Informal moderated group discussions on particular questions and predominant answers aimed at deepening authors' understanding of respondents' motivations and decision-making patterns. This part of research allowed to deepen the answers to the questionnaire and place them in a wider societal context, which is the main strength of the presented research.

The main limitation of applied research methodology is the mixed nature of decision-making determinants, which are both qualitative and quantitative. In order to overcome this problem the AHP methodology, which allows to transpose qualitative criteria into quantitative data has been selected for future elaboration of the model. Another weakness is the composition of research sample from University students, which can limit the findings to questioned part of the population. Explanatory research stage repeatedly undertook this issue to discover whether one can extrapolate the findings on a larger Youth sample that the one investigated here.

Findings limitations can be explained by a quote from Jungeilges and Theisen (2008, p. 1092) who observe that: "it may be very hard to describe the multitude of differences between societies, differences in social background, and differences in future prospects, by a manageable set of constraints on individual policy choices (and therefore) a coherent theoretical framework is needed for designing experiments of individual choices between different policies, and for interpreting the results from such experiments".

Throughout the presented research the authors were aware of the specifics of individual preferences on socio-economic conditions in multicriteria decision-making, i.e. differences in constraint (unconstrained preferences and meta-preferences), stability of preferences over time, the role of socialization and internal or external influences in the 
process of formation of preferences, social choice capability and limitations and others (Jungeilges \& Theisen, 2008, pp. 1092-1094). These issues have been discussed in a study on the formation of social preferences by Jungeilges and Theisen (2008).

\section{RESULTS AND DISCUSSION}

\section{Outcome from Exploratory and Explanatory Research}

Out of 236 respondents $44 \%$ of the students were males (103 respondents - "r.") and $56 \%$ were females (133 r.). Their age varied from under 20 (61 r. $=26 \%)$, through 20-25 (140 r. = 59\%) and 26-30 (11 r. = 5\%), until above $30(24$ r. = 10\%) - therefore the biggest number of answers have been obtained from students aged between 20 and 25 . This can be explained by the countrywide availability of tertiary education system for alumni of secondary education. The prevailing majority of respondents were from Norway ( $233 \mathrm{r}$. = 99\%), with 1 from Russia, 1 from a non-EU country and 1 who skipped this question).

Almost $6 \%$ (13) of respondents finished secondary level of education, close to $3 \%$ (6 r.) finished additional vocational training, $24 \%$ (57 r.) held a Bachelor title and 1\% (2 r.) had a Master. $55 \%$ of respondents (130 r.) were still students of a Bachelor Programme and $12 \%$ (28) were Master Programme students. No respondents held a Doctor title. Most of respondents were part-time employed $(50 \%=118$ r.), $41 \%$ (97 r.) were unemployed, an equal number was self-employed and permanently employed ( $4 \%=10 \mathrm{r}$.). One person skipped that question. The distribution of function of work experience in time was quite flat, with $27 \%$ (63 r.) with no work experience at all, $12 \%$ ( $28 \mathrm{r}$.) with less than 1 year, 25\% (58 r.) with 1-3 years, 18\% (42 r.) between 3-5 years and 19\% (44) with more than 5-year work experience. One respondent skipped that question. A quite high level of students with work experience (around 73\%) can be explained by a relatively high availability of work posts for young people. Another explanation comes from a general willingness of Norwegian Youth to cover at least a part of their maintenance costs when studying on their own. It is important to underline that this need is rarely coerced by the income level of their parents (provided easy accessibility of educational grants), it comes rather from the need for independence, understood inter alia as responsibility for one's own keep.

The housing situation of the respondents was the following: $9 \%(21 \mathrm{r}$.) lived in rural areas, almost $31 \%$ (72 r.) in cities below 50.000 inhabitants, 55\% (129 r.) in cities between 50000 and 100000 inhabitants, close to 6\% (13 r.) in cities between 100000 and 500000 inhabitants and 1 person (less than 0,5\%) in a city above 500000 inhabitants. $15 \%$ (35 r.) still lived with their parents, 23\% (55 r.) with their partner, surprisingly only $12 \%$ (29 r.) in their own flat, 3\% (7 r.) were sharing their own flat with other people. Corenting an apartment with other people was most popular $(40 \%=95$ r.), University hostel was inhabited by $6 \%$ (14 r.). One person skipped that question.

Questions about the income gave the authors a first insight into perceptions of respondents. The monthly income of $16 \%$ (37 r.) was below $300 €, 12 \%$ (29 r.) earned between 300 and $500 €, 50 \%$ (117 r.) between 500 and $1000 €$ and 22\% (52 r.) above $1000 €$. One respondent skipped that question. Interesting to notice was that at very high daily upkeep in Norway income satisfaction of Norwegian Youth seemed to be quite reasonable: $1 \%(2 \mathrm{r}$.) assessed their monthly income as very high, 9\% (22) as rather high, 45\% 
(106 r.) as appropriate, 32\% (76 r.) as rather low and 12\% (29 r.) as very low. 1 respondent skipped that question. This means that however $44 \%$ of respondents assessed their monthly income as not sufficient, $56 \%$ stated the opposite. This in turn means that despite high costs of living and a general tendency for understating income perceptions, the majority of respondents were happy with their earnings.

Additional information pointed at sources of income: for close to $6 \%$ (13 r.) it was respondent's parents, for the same amount it was their partner, around $50 \%$ received a scholarship and a government educational loan from Lånekassen (118 r. altogether), $10 \%$ (24 r.) a bank loan, $25 \%$ (60 r.) were living on their own savings and $3 \%$ ( 8 r.) pointed at combinations of the above (with two single mothers receiving additional state aid). Also the income expectations after graduating were reasonable (taking into account their education, market conditions and salary levels): $1 \%$ ( 2 r.) were expecting a salary below $500 €$ per month, same amount targeted at 500-1000€, 6\% (15 r.) at 1000-2000€, and a similar amount of $47 \%$ (110 r.) and $45 \%$ (106 r.) would be happy respectively with 2000-4000€ and more than $4000 €$ per month. One respondent skipped that question. At the same time $8 \%$ (19 r.) saw their income level as of utmost importance for their QoL, $41 \%$ (97 r.) as highly important, 44\% (103 r.) as important and 7\% (17 r.) as not important. Nobody marked "not at all important" option.

Insight into respondents' perceptions followed with individual assessment of their free time. Also here the majority of respondents showed satisfaction, with almost $78 \%$ being happy in this area. 9\% (22 r.) declared to have a lot of free time, 11\% (25 r.) rather a lot, $58 \%(137$ r.) enough and only $17 \%$ ( 40 r.) rather little or very little (5\%=12 r.).

The future professional position was important to the outstanding majority of the respondents (almost 95\%), with 12\% (29 r.) declaring it to be most important, $47 \%$ (112 r.) as highly important, $36 \%(84$ r.) as important and only for $4 \%(9$ r.) as of little importance or not important at all $(1 \%=2 \mathrm{r}$.). Another strong preference has been observed for the place of family in respondents' lives. $26 \%$ (61 r.) perceived family as of utmost importance for them, $61 \%$ (144 r.) as one, but not unique, most important parts of their lives, $10 \%$ (24 r.) declared its importance as equal to other areas and almost $3 \%$ (6 r.) declared themselves as not family oriented. Nobody stated absolute indifference about family, although one person skipped that question.

Respondents' observations about the society proved to be interesting, too. $4 \%$ (10 r.) felt confident only inside the Norwegian society. The vast majority could consider living in another society (almost 94\%), although for $34 \%$ (80 r.) it could prove to be difficult. $53 \%$ (122 r.) could easily change their society, $7 \%$ (16 r.) did not see society as important to their QoL and for $2 \%$ (4 r.) did not define themselves as part of any society. It has to be explained, that the term "society" has been freely defined by the respondents, with a general guideline as their living environment, including their entourage, customs, tradition, culture, language and anything else that could help determining it.

The core of presented research were the rankings of significance of QoL determinants by Norwegian students. The respondents have been asked to rate the relevance of each QoL determinant with regard to its relevance to their QoL. The rankings were based on a 5 -point Likert-type scale, where 5 is very important and 1 is not important at all. The sample size was $n=236$, but not every question has been answered by every respondent. Therefore a total score has been calculated for each determinant. Its calculation modus 
was the sum of products of the number of students that attributed this particular determinant with a certain rank and its value. Results of significance ranking of QoL determinants by Norwegian Youth can be found in Table 1 below (sorted in descending order). Optional additional answers of four respondents that ranked as most important their relationship with God, love, wealthy spouse or gender equality have not been mentioned.

Table 1. Significance of quality life determinants in the eyes of Norwegian Youth

\begin{tabular}{|l|c|c|c|c|c|c|}
\hline \multirow{2}{*}{\multicolumn{1}{|c|}{ Determinants of quality of life }} & \multicolumn{3}{|c|}{$\begin{array}{c}\text { Distribution of answers (in \%) } \\
\text { along the established rank scale }\end{array}$} & $\begin{array}{c}\text { Total } \\
\text { score }\end{array}$ \\
\cline { 2 - 7 } & $\mathbf{1}$ & $\mathbf{2}$ & $\mathbf{3}$ & $\mathbf{4}$ & $\mathbf{5}$ & \\
\hline Keeping contact with family and friends & 0.93 & 3.74 & 7.01 & 22.90 & 65.42 & 959 \\
\hline Having a stable job & 0.93 & 1.87 & 8.88 & 26.64 & 61.68 & 955 \\
\hline Having an interesting job & 0.93 & 0.93 & 10.28 & 28.50 & 59.35 & 951 \\
\hline Ability to obtain a well-paid job & 0.47 & 1.88 & 14.08 & 39.91 & 43.66 & 904 \\
\hline Living without fear about the future & 1.40 & 2.80 & 14.95 & 34.58 & 46.26 & 902 \\
\hline Being able to develop professionally & 1.88 & 1.41 & 16.90 & 43.19 & 36.62 & 876 \\
\hline Ability to save money & 1.88 & 4.23 & 15.02 & 40.38 & 38.50 & 872 \\
\hline Free and safe travelling in an open World & 2.35 & 3.76 & 21.60 & 27.23 & 45.07 & 871 \\
\hline Being able to pursue self-development & 0.93 & 3.27 & 21.03 & 40.19 & 34.58 & 865 \\
\hline Being able to combine private \& professional life & 3.29 & 6.10 & 22.07 & 26.29 & 42.25 & 848 \\
\hline Having free time & 0.93 & 6.54 & 22.43 & 35.51 & 34.58 & 848 \\
\hline Having basic access to information & 1.41 & 4.23 & 22.07 & 40.38 & 31.92 & 846 \\
\hline Predictability of consequences of own actions & 2.83 & 2.36 & 21.23 & 42.45 & 31.13 & 841 \\
\hline Retirement pension level in the future & 3.29 & 4.23 & 22.54 & 34.74 & 35.21 & 840 \\
\hline A proper work-life balance & 2.80 & 3.74 & 23.36 & 38.32 & 31.78 & 840 \\
\hline Working accordingly to own qualifications & 1.87 & 5.61 & 21.03 & 45.33 & 26.17 & 831 \\
\hline Geopolitical safety and stability & 2.82 & 6.10 & 28.17 & 27.70 & 35.21 & 823 \\
\hline Level of income & 0.47 & 3.27 & 26.64 & 50.93 & 18.69 & 822 \\
\hline Living accordingly to high legal and societal standards & 4.27 & 4.27 & 28.91 & 31.75 & 30.81 & 803 \\
\hline Being useful to the society & 4.67 & 7.48 & 24.30 & 40.19 & 23.36 & 792 \\
\hline Cost of living & 2.35 & 7.04 & 50.23 & 30.52 & 9.86 & 721 \\
\hline Not being victim to "information overload" & 5.61 & 9.81 & 45.79 & 30.84 & 7.94 & 697 \\
\hline Level of debt to pay back after graduating & 7.98 & 19.72 & 37.56 & 25.35 & 9.39 & 657 \\
\hline Level of risk related to financial investments & 11.68 & 16.36 & 45.79 & 20.56 & 5.61 & 625 \\
\hline
\end{tabular}

Source: own elaboration based on research results.

Interpretation of the results: after a minutious analysis some groups of factors can be derived from the general set. Although a general division between material and nonmaterial determinants seems to be the most obvious, respondents' opinions obtained in explanatory research persuaded the authors to adopt thematic grouping criterion. Groups of determinants have been presented in descending order respectively to the average ranking of a single determinant from each group, calculated as the sum of total scores of determinants from the given group and divided by their amount (values in brackets). These are: (i) safety, stability and certainty $(891,8)$; (ii) continuous self- 
development $(876,5)$; (iii) work-life balance $(845,3)$; (iv) freedom and society $(784,5)$; (v) finance $(773,3)$. Grouping of determinants that could be attributed to more than one group finally occurred on basis of group discussions with respondents lead in explanatory research phase.

In the first group, "safety, stability and certainty", "Keeping contact with family and friends" has been ranked as most important. 2nd highest importance has been granted to "Having a stable job". A correlation can also be observed with "Living without fear about the future" that has been ranked 5th. Other determinants from this group have been ranked lower: "Free and safe travelling in an open World" as 8th, "Predictability of consequences of my actions" 13th, "Geopolitical safety and stability" 17th. Nevertheless, the average individual ranking of determinants from this group makes it the most relevant for respondents' QoL. This can be due to the phenomenon brought up in explanatory research - a general feeling of safety omnipresent in Norwegian society. Respondents pointed at the welfare state as its cause.

The group ranked as second, "continuous self-development", consisted of such determinants as "Having an interesting work" (ranked 3rd), "Being able to develop professionally" - 6th, "Being able to pursue self-development" - 9th, and "Working accordingly to my qualifications" - 16th. A high level of self-awareness of Norwegian society can be backed by statistical data, putting Norway on the very top of 2015 Human Development Index (HDI) list and at the same place of Inequality-adjusted HDI by the United Nations Development Programme (UNDP, 2015).

"Being able to combine private and professional life" (10th), "Free time" (11th) and "A proper work-life balance" (15th) composed the third group, "work-life balance". Average individual ranking of determinants keep it closer to groups (i) and (ii), than to groups (iv) and (v). In 2015 Norway opened the Legatum Prosperity Index list as the country that provides the highest aggregated level of wealth, economic growth, education, health, personal well-being and QoL out of 142 countries (Legatum Institute, 2015).

"Freedom and society" was composed of "Having basic access to information" (12th), "Living accordingly to high legal and societal standards" (19th), "Being useful to the society" (20th) and "Not being victim to information overload" (22nd). The highest ranked determinant in this group falls in the middle of ranking only, which justifies the low average-based overall rating of this group of determinants. It can be explained by the fact that freedom and societal values tend to be underestimated until their lack becomes visible. Norway placed also 2nd in 2015 Press Freedom Index ranking (Reporters Without Borders, 2015).

Last in ranking was "finance", composed of "Ability to obtain a well-paid job" (4th), "Ability to save money" (7th), "Retirement pension level in the future" (14th), "Level of income" (18th), "Cost of living" (21st), "Level of debt to pay back after graduating" (23rd) and "Level of risk related to financial investments" (24th). The lowest grade of incomerelated QoL determinants can be explained by a very high financial standard of living in Norway, with high income per capita, low income distribution discrepancy and a multitude of social mechanisms preventing poverty. In World Bank's GDP per capita based on purchasing power parity 2015 ranking Norway reached 8th position with 65614,5 USD of yearly PPP-based per capita income (World Bank, 2015). Moreover, respondents pointed 
also at non-stigmatization of business failures as being part of the entrepreneurial mechanism.

It was interesting to notice, that although some material QoL determinants have been ranked quite high, generally their individual average ranking was the lowest. At the same time, in a similar survey lead in Russia, even though determinants linked with stability, certainty and confidence have been ranked very high, income related factors were perceived as more significant for high QoL. Figure 1 shows the above ranking in a graphical way (in descending order of total scores).

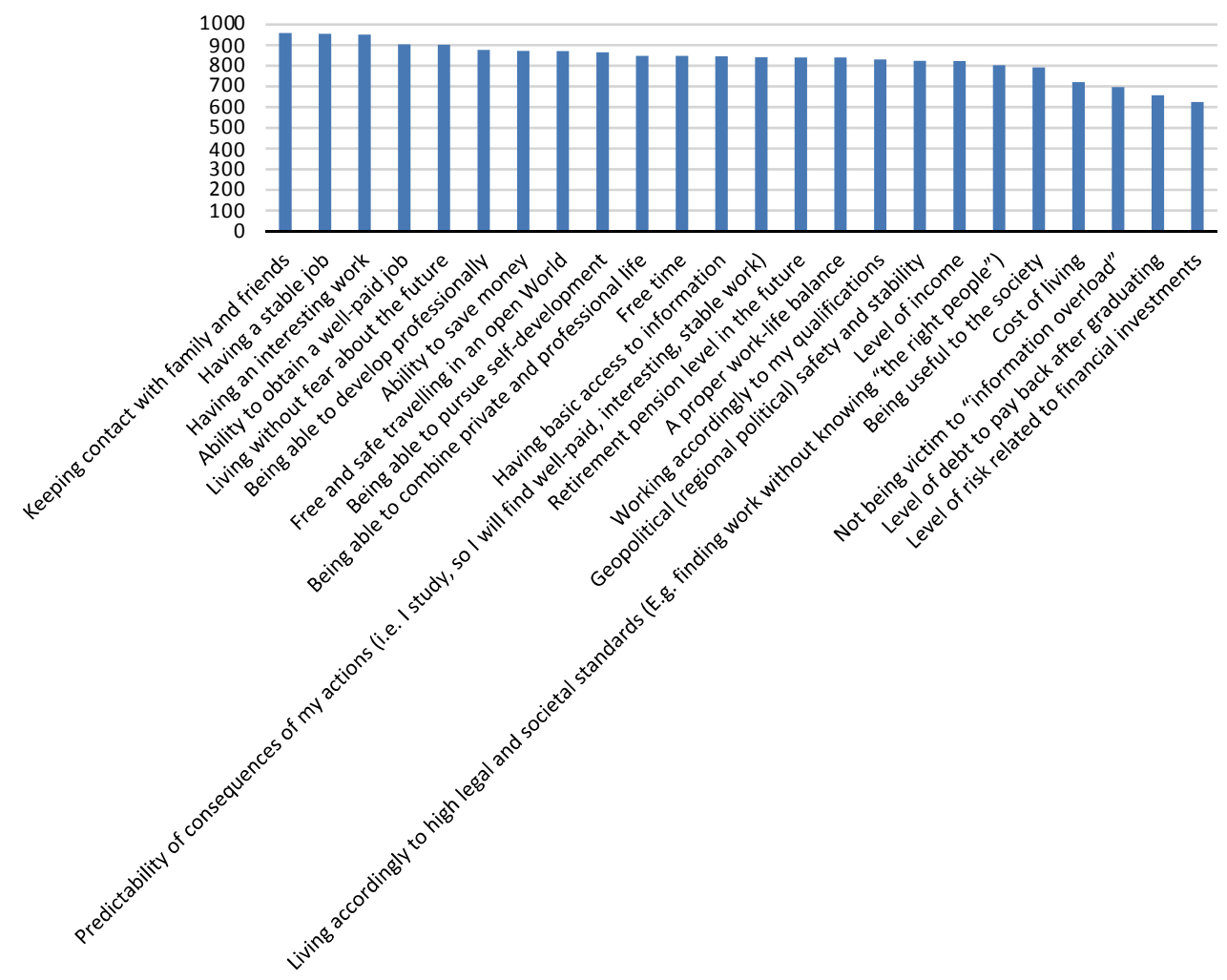

Figure 1. Ranking of quality of life determinants - graphical presentation Source: own elaboration based on research results.

In the last step the respondents had to sort alternative life strategies accordingly to their attractiveness in relation to their rankings of QoL determinants from Table 1 . The distribution of answers presented in Table 2 has been based on total grade of life strategy attractiveness, calculated similarly to total scores above. The scale has been reversed, though, as the lowest grade means the most attractive life strategy.

It can be seen that the family-oriented strategy is perceived as the most attractive, whereas income-oriented comes only second, almost at the same level as the careeroriented one. Time-oriented strategy, targeted at maximizing the amount of respondent's free time has been ranked fourth in attractiveness. Apparently only singular respondents felt attracted by living outside the societal mainstream. Explanatory research 
gave some insight into the reasons for such a grading. In fact, Norwegian Youth on their way to independence feel a strong financial, substantive and psychological support from various parties, including family, friends, public institutions and private sector. Norwegian respondents clearly stated that the multitude of opportunities creates a societal pressure (at home, at school, but also from their friends) to profit of it at any cost because everybody does, because it is available. Strangely enough, respondents underlined that this rises the fear of failure and deepens the feeling of defeat in case of one. This in turn explains the attractiveness of the family-oriented strategy (where success usually is not the decisive measure), but also of the "opting-out" strategy - as an escape solution for some respondents. A relatively low attractiveness of free-time strategy can be partially explained by the fact that this resource starts becoming valuable with its growing scarcity - and it has been ranked only 11th in terms of relevance for QoL. In explanatory research most respondents assessed their actual amount of free time as sufficient.

Table 2. Attractiveness of life strategies for Norwegian Youth

\begin{tabular}{|l|c|c|c|c|c|c|}
\hline \multirow{2}{*}{\multicolumn{1}{|c|}{ Life strategies }} & \multicolumn{2}{|c|}{$\begin{array}{l}\text { Distribution of the answers (in \%) } \\
\text { along the established grade scale }\end{array}$} & $\begin{array}{l}\text { Total } \\
\text { grade }\end{array}$ \\
\cline { 2 - 7 } & $\mathbf{1}$ & $\mathbf{2}$ & $\mathbf{3}$ & $\mathbf{4}$ & $\mathbf{5}$ & \\
\hline Income-oriented (constantly increasing your salary) & 47.00 & 24.50 & 14.50 & 11.00 & 3.00 & 397 \\
\hline $\begin{array}{l}\text { Family-oriented (working only until your job is not interfer- } \\
\text { ing with your family obligations) }\end{array}$ & 16.16 & 28.28 & 31.82 & 19.19 & 4.55 & 530 \\
\hline Career-oriented (becoming "somebody important") & 25.37 & 19.90 & 21.89 & 17.41 & 15.42 & 558 \\
\hline Time-oriented (maximizing the amount of your free time) & 10.66 & 24.37 & 24.37 & 35.03 & 5.58 & 592 \\
\hline $\begin{array}{l}\text { Opting - out from the entire socio-economic system (living } \\
\text { outside the mainstream) }\end{array}$ & 3.11 & 3.63 & 7.25 & 16.06 & 69.95 & 861 \\
\hline
\end{tabular}

Source: own elaboration based on research results.

Graphical presentation of these results can be found on Figure 2 (in ascending order of total grades, from most to least attractive).

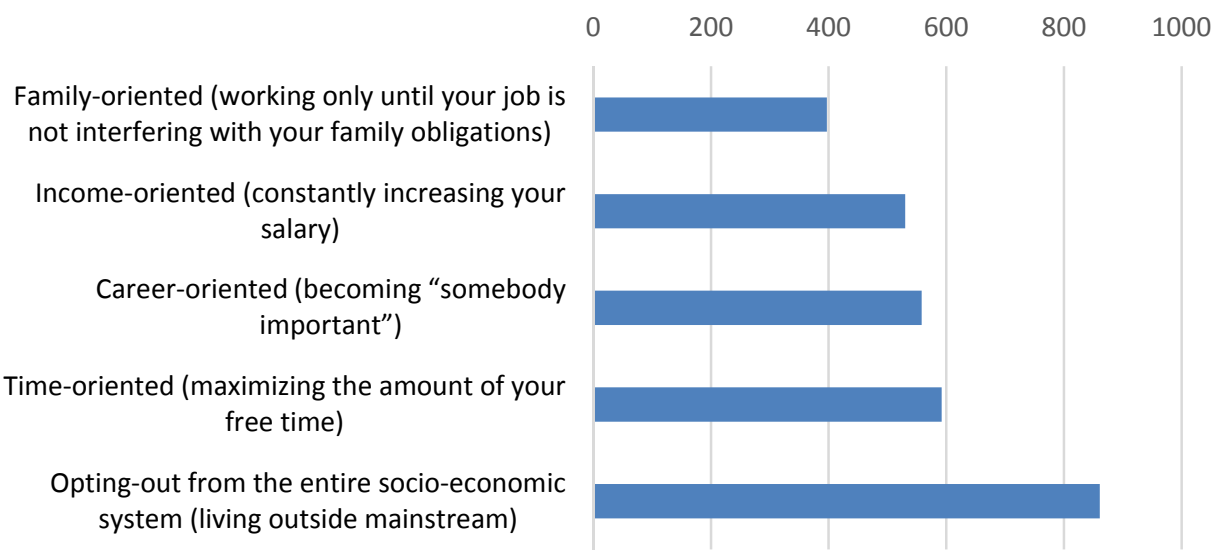

Figure 2. Total grades of life strategy attractiveness (from most to least attractive) Source: own elaboration based on research results. 
The authors are aware of the fact that presented research results can be perceived as relevant for the questioned target group only. Nevertheless, if perceived in frames of weak signal approach, obtained answers (especially from explanatory research) can point at possible features of the whole generation of actual Youth. Holopainen and Toivonen (2012, p. 198) summarize Ansoff's (1975) weak signals approach as: "an alternative or supplement to strategic planning (...) that (...) is reasonable in the case of incremental development of historical trends, but it is not successful when dealing with surprises".

In fact, the phenomena actually forming the employees and entrepreneurs of the nearest future are not linear anymore, their rather bear a non-linear, shock-susceptible characteristic, that indeed could be defined as a recurring set of "surprises" in decisionmaking micro- and macro-environment. In the opinion of Holopainen and Toivonen, (2012, p. 198): "in circumstances where the rate of change is continuously accelerating, a more reasonable approach is to increase strategic flexibility and determine which actions will be feasible when the detailed information becomes available. This kind of approach can be called response to weak signals". Adopting the weak signals logics to work-life balance implies the need for adaptation of company's HRM practices.

\section{Implications for Human Resources Management}

Presented research on QoL determinants has brought us to conclude that higher levels of motivation, entrepreneurship and responsibility at work can be achieved by providing young people with: (i) freedom in their decision-making; (ii) a working environment that allows the employees to develop their natural capabilities and abilities; (iii) safe-landing mechanisms for potential failures; (iv) fair salaries with reasonable discrepancies between highest and lowest income levels; ( $v$ ) fair treatment in working environment; (vi) support (or do not discouragement) of entrepreneurship.

Obtained research results confirmed the hypothesis saying that an early elaboration of individual hierarchy of QoL determinants, including work-life balance, can enhance the ability of Youth to make conscious choices about their future professional careers and personal development and as such contribute to higher efficiency of their professional activities. Therefore HR managers should consider a more individualistic approach in their search for independent and effective personnel. Especially explanatory research responses pointed at the need of Norwegian Youth to be approached individually, leaving space for particular combinations of work-life balance determinants as a strong motivation mechanism at work.

Conducted research has also shown that preferred levels of above factors are individual specific, therefore managers, including HR specialists, should adopt a more individual-focused approach to their actual employees, as well as to the candidates for work posts. It definitely is more resource consuming that a standardized approach to human resource management, but allows to expect a higher efficiency in solving unconventional tasks. Future research could determine to which extent this general remark stands for various working environments and for different positions.

In parallel, at societal level the policy-making should focus on: (i) assuring an optimal balance between activities assured by private and public sectors; (ii) improving the societal standards by educating on democracy and freedom, exacting transparency in state institutions and private companies, fighting corruption, building confidence in citizens since early childhood through positive cognitive education, supporting independent and 
reliable media; (iii) creating development opportunities for entrepreneurs; (iv) preserving equality in access to public services, but at the same time guard the system from misusers; ( $v$ ) assuring the sustainability and quality of public services by grading the priorities in distribution of public goods and amounts to be distributed to each individual (re-defining the equality rule); (vi) creating service-specific efficiency measurement models, including both material and non-material determinants of service quality; (vii) providing space for all forms of development (in business and public sphere, oriented on material and non-material added value).

\section{CONCLUSIONS}

The presented research was the next step towards creation of a multicriteria AHP-based model that would support young people in their early-career decision-making. Research methodology consisted of a literature analysis, exploratory and explanatory research with application of direct interviews, a web-based survey and moderated group discussions.

The research target group has been composed of 236 respondents recruited between Norwegian tertiary education students. Research placement in Norway aimed at giving insight into the significance of QoL determinants and attractiveness of various life strategies in a socio-economically developed society. Obtained rankings allowed to draw following implications for HRM practice: (i) a potential for growth of employees' efficiency and motivation exists, but in Norwegian reality requires a more individualized, personoriented managerial approach; (ii) it can be achieved by offering each employee a suitable, individual specific combination of work-life balance determinants, based on his/her preferences; (iii) better results can be achieved if internal HRM processes in companies find support in economic and social policies of the government.

The substantial research limitation came from the research sample, although if perceived through Ansoff's (1975) weak signal approach, it can still provide some directions for future research. It should concentrate on analysing whether the individualistic HRM approach described in the present paper benefits the employees and their employer similarly at different work posts.

\section{REFERENCES}

Abel-Smith, B., \& Townsend, P. (1965). The poor and the poorest. Occasional Papers on Social Administration, 17.

Adame, C., Caplliure, E-M., \& Miquel, M-J. (2016). Work-life balance and firms: A matter of women? Journal of Business Research, 69(4), 1379-1383. doi: 10.1016/j.jbusres.2015.10.111

Alfes, K., Shantz, A.D., Truss, C., \& Soane, E.C. (2013). The link between perceived human resource management practices, engagement and employee behaviour: a moderated mediation model. The International Journal of Human Resource Management, 24(2), 330-351.

Alkire, S., \& Foster, J. (2011). Counting and multidimensional poverty measurement. Journal of Public Economics, 95, 476-487.

Anand, P., Krishnakumar, J., \& Tran, N.B. (2011). Measuring welfare: Latent variable models for happiness and capabilities in the presence of unobservable heterogeneity. Journal of Public Economics, 95, 205-215. 
Ansoff, H.I. (1975). Managing strategic surprise by response to weak signals. Californian Management Review, 18(2), 21-33.

Atkinson, A.B. (1983). The Economics of Inequality. $2^{\text {nd }}$ edition. Oxford: Clarendon Press.

Atkinson, A.B. (2003). Multidimensional deprivation: contrasting social welfare and counting approaches. Journal of Economic Inequality, 1, 51-65.

Baron, J.N., Jennings, P.D., \& Dobbin, F.T. (1988). Mission control? The development of personnel systems in U.S. industry. American Sociological Review, 53, 497-514.

Boreham, P., Povey, J., \& Tomaszewski, W. (2016). Work and social well-being: the impact of employment conditions on quality of life. The International Journal of Human Resource Management, 27(6), 593-611.

Chang, J., Travaglione, A., \& O'Neill, G. (2015). How can gender signal employee qualities in retailing? Journal of Retailing and Consumer Services, 27, 24-30, doi: 10.1016/j.jretconser.2015.07.004

Gawlik, R. (2013). Material and non-material determinants of European youth's life quality. In N. Delener, L. Fuxman, F.V. Lu, S. Rodrigues \& L.E. Rivera (Eds.), Globalizing Businesses for the Next Century: Visualizing and Developing Contemporary Approaches to Harness Future Opportunities (pp. 339-346). New York, NY: Global Business and Technology Association.

Gawlik, R. (2014). Zastosowanie metody Analitycznego Procesu Sieciowego do wspierania racjonalnych wyborów młodych Europejczyków. Prace Naukowe Uniwersytetu Ekonomicznego we Wrocławiu: Nowe kierunki w zarzq̨dzaniu przedsiębiorstwem - wiodq̨ce orientacje, 340, 415426.

Gawlik, R. (2015). Zmiany parametrów jakości życia Młodych Europejczyków - implikacje dla przedsiębiorstw. In E. Małuszyńska, G. Mazur \& P. Idczak (red.), Unia Europejska wobec wyzwań przyszłości, Aspekty społeczne, gospodarcze i środowiskowe (pp. 13-22). Poznań: Wyd. Uniwersytetu Ekonomicznego w Poznaniu.

Gawlik, R., Titarenko, R., \& Titov, S. (2015). Perception of Quality of Life and Its Components between Russian Students and Its Implications for University Lecturers. Horyzonty Polityki: Polityka publiczna, 6(16), 127-150.

Ginevičius, R., Gedvilaitè, D., \& Bruzgè, Š. (2015). Assessment of a Country's Regional Economic Development on the Basis of Estimation of a Single Process (ESP) Method. Entrepreneurial Business and Economics Review, 3(2), 141-153.

Gries, T., \& Naudé, W. (2011). Entrepreneurship and human development: A capability approach. Journal of Public Economics, 95, 216-224.

Holopainen, M., \& Toivonen, M. (2012). Weak signals: Ansoff today. Futures, 44, 198-205. doi: 10.1016/j.futures.2011.10.002

Huselid, M.A., Jackson S.E., \& Schuler, R.S. (1997). Technical and strategic human resource management effectiveness as determinants of firm performance. The Academy of Management Journal, 40(1), 171-188.

Jackson S.E., Schuler, R.S., \& Jiang, K. (2014). An aspirational framework for strategic human resource management. The Academy of Management Annals, 8(1), 1-56.

Jungeilges, J., \& Theisen, T. (2008). A comparative study of equity judgements in Lithuania and Norway. Journal of Socio-Economics, 37, 1090-1118.

Kehoe, R.R., \& Wright, P.R. (2013). The Impact of High-Performance Human Resource Practices on Employees' Attitudes and Behaviors. Journal of Management, 39(2), 366-391.

Khan, H. (1990). Measurement and Determinants of Socioeconomic Development: A Critical Conspectus. Social Indicators Research, 24(2), 153-175. 
Kirk, S. (2016). Career capital in global Kaleidoscope Careers: the role of HRM. The International Journal of Human Resource Management, 27(6), 681-697.

Layard, R. (2005). Happiness: Lessons from a New Science. New York, NY: Penguin Press.

Legatum Institute (2015). Legatum Prosperity Index. Legatum Institute. Retrieved on May 17, 2016 from http://media.prosperity.com/2015/pdf/publications/PI2015Brochure_WEB.pdf

Lub, X.D., Bal, P.M., Blomme, R.J., \& Schalk, R. (2016). One job, one deal... or not: do generations respond differently to psychological contract fulfilment? The International Journal of Human Resource Management, 27(6), 653-680. doi: 10.1080/09585192.2015.1035304

Maslow, A. (1954). Motivation and Personality. New York, NY: Harper.

Neumark, D., \& Muz, J. (2016). The "Business Climate" and Economic Inequality. Review of Income and Wealth, 62(1), 161-180. doi: 10.1111/roiw.12146

Parakandi, M., \& Behery, M. (2016). Sustainable human resources: Examining the status of organizational work-life balance practices in the United Arab Emirates. Renewable \& Sustainable Energy Reviews, 55, 1370-1379. doi: 10.1016/j.rser.2015.07.095

Perls, F. (1942). Ego, hunger and aggression. Durban: Knox Publishing.

Perls, F., Hefferline, R., \& Goodman, P. (1951). Gestalt therapy: excitement and growth in the human personality. New York, NY: Julian Press.

Perls, F. (1969). Gestalt therapy verbatim. Lafayette, CA: Real People Press.

Pocztowski, A. (2008). Zarzqdzanie zasobami ludzkimi: strategie, procesy, metody. Warszawa: Polskie Wydawnictwo Ekonomiczne.

Presbitero, A., Roxas, B., \& Chadee, D. (2016). Looking beyond HRM practices in enhancing employee retention in BPOs: focus on employee-organisation value fit. The International Journal of Human Resource Management, 27(6), 635-652.

Ren, X., \& Caudle, D. (2016). Walking the tightrope between work and non-work life: strategies employed by British and Chinese academics and their implications. Studies in Higher Education, 41(4), 599-618. doi: 10.1080/03075079.2014.942277

Reporters Without Borders (2015). Press Freedom Index. Reporters Without Borders. Retrieved on May 17, 2016 from https://rsf.org/en/ranking/2015

Russo, M., Shteigman, A., \& Carmeli, A. (2016). Workplace and family support and work-life balance: Implications for individual psychological availability and energy at work. The Journal of Positive Psychology, 11(2), 173-188. doi: 10.1080/17439760.2015.1025424

Schuessler, K.F., \& Fisher, G.A. (1985). Quality of Life Research and Sociology. Annual Review of Sociology, 11, 129-149. doi: 10.1146/annurev.so.11.080185.001021

Sen, A.K. (1979). Personal utilities and public judgements: or what's wrong with welfare economics? Economic Journal, 89(355), 537-558.

Sen, A.K. (1985). Commodities and capabilities. Oxford: Oxford University Press.

Sen, A.K. (1992). Inequality Reexamined. Oxford: Clarendon Press.

Sen, A.K. (1993). Capability and wellbeing. In M. Nussbaum \& A.K. Sen (Eds.), The Quality of Life (pp. 30-53). Oxford: Oxford University Press.

Sen, A.K. (1999). Development as freedom. Oxford: Oxford University Press.

Simkins, T.J., \& Peterson, M. (2016). Assessing the Value of a Societal-Level Sustainability Index for Macromarketing Research. Journal of Macromarketing, 36(1), 78-95.

Smith, A. (1759). The theory of moral sentiments. Strand \& Edinburgh: A. Millar, A. Kincaid \& J. Bell. 
Stec, M., Filip, P., Grzebyk, M., \& Pierscieniak, A. (2014). Socio-Economic Development in the EU Member States - Concept and Classification. Inzinerine Ekonomika-Engineering Economics, 25(5), 504-512. doi: 10.5755/j01.ee.25.5.6413

Stiglitz, J., Sen, A., \& Fitoussi, J-P. (Eds.) (2009). Report by the Commission on the Measurement of Economic Performance and Social Progress. Paris: Commission on the Measurement of Economic Performance and Social Progress.

Şerban-Oprescu, G. (2012). Economic Approaches to Sustainability and Quality of Life. An Epistemological Study. The Romanian Economic Journal, 46 bis, 79-96.

Tang, Y., \& Hornung, S. (2015). Work-family enrichment through I-Deals: evidence from Chinese employees. Journal of Managerial Psychology, 30(8), 940-954.

Tolbert, P.S., \& Zucker, L.G. (1983). Institutional sources of change in organizational structure: The diffusion of civil service reform. Administrative Science Quarterly, 23, 22-39.

Ulman, P., \& Šoltés, E. (2015). The monetary and non-monetary aspects of poverty in Poland and Slovakia. Entrepreneurial Business and Economics Review, 3(1), 61-73.

UNDP (2015). Human Development Report. United Nations Development Programme. Retrieved on May 17, 2016 from http://hdr.undp.org/sites/default/files/hdr_2015_statistical_annex.pdf

Urbaniec, M. (2015). Sustainable Development Indicators in Poland: Measurement and System Evaluation. Entrepreneurial Business and Economics Review, 3(1), 119-134.

Uysal, M., Sirgy, M.J., Woo, E., \& Kim, H. (2016). Quality of life (QoL) and well-being research in tourism. Tourism Management, 53, 244-261. doi: 10.1016/j.tourman.2015.07.013

World Bank (2015). World Development Indicators Database. World Bank. Retrieved on May 17, 2016 from http://data.worldbank.org/indicator/NY.GDP.PCAP.PP.CD?order=wbapi_data_ value_2014+wbapi_data_value+wbapi_data_value-last\&sort=desc

Zheng, C., Kashi, K., Fan, D., Molineux, J., \& Shan Ee, M. (2016). Impact of individual coping strategies and organisational work-life balance programmes on Australian employee well-being. The International Journal of Human Resource Management, 27(5), 501-526.

Żur, A. (2015). Social Problems as Sources of Opportunity: Antecedents of Social Entrepreneurship Opportunities. Entrepreneurial Business and Economics Review, 3(4), 73-87. 


\section{Authors}

The contribution share of authors is equal and amounted to $50 \%$ each of them.

\section{Remigiusz Gawlik}

Assistant Professor at Cracow University of Economics (Poland), Faculty of Economics and International Relations, International Economics Department. PhD in Economics at Cracow University of Economics (Poland). Alumnus of the College of Europe (Belgium \& Poland). Certified Gestalt Counsellor and consultant in business communication. His scientific interests include modelling of decision-making processes in various fields of management.

Correspondence to: Dr. Remigiusz Gawlik; Cracow University of Economics, Faculty of Economics and International Relations, International Economics Department; ul. Rakowicka 27, 31-510 Kraków, Poland; e-mail: remigiusz.gawlik@uek.krakow.pl

\section{Gorm Jacobsen}

Associate Professor at the University of Agder (Norway), Faculty of Economics and Social Sciences, Department of Working Life and Innovation. Bachelor in Business Administration from the University of Lund (Sweden), Master Economics from the University of Oslo (Norway). His scientific interests include transformation from centrally planned economy to market economy and its implications.

Correspondence to: Assoc. Prof. Gorm Jacobsen, PhD; University of Agder, Department of Working Life and Innovation; F158, Jon Lilletunsvei 9, 4879 Grimstad, Norway; e-mail: gorm.jacobsen@uia.no

\section{Acknowledgements and Financial Disclosure}

The authors would like to thank all respondents to the questionnaire as well as participants to direct interviews. Special thanks are addressed to prof. Arne Inaksen from the University of Agder, Campus Grimstad and prof. Theis Theisen from the University of Agder, Campus Kristiansand.

This research was supported by the National Science Centre of Poland (decision No.: DEC-2013/11/D/HS4/04070) within a research project entitled "The Application of Analytic Hierarchy Process for Analyzing Material and Non-material Determinants of Life Quality of Young Europeans" led by Remigiusz Gawlik, PhD between 2014 and 2017.

\section{Copyright and License}

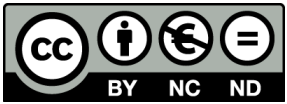

This article is published under the terms of the Creative Commons Attribution - NonCommercial - NoDerivs (CC BY-NC-ND 3.0) License http://creativecommons.org/licenses/by-nc-nd/3.0/ 